\title{
ASSESSMENT OF THE GREENERY PLANTING LEVEL IN SANITARY PROTECTION ZONES OF THE DNIPROPETROVSK INDUSTRIAL ENTERPRISES
}

\author{
Horova A.I., Buchavy Yu.V.
}

\section{ОЦПНКА СТУПЕНЯ ОЗЕЛЕНЕННЯ САНІТАРНО-ЗАХИСНИХ ЗОН ПРОМИСЛОВИХ ПІДПРИЕМСТВ ДНПРОПЕТРОВСЬКА}

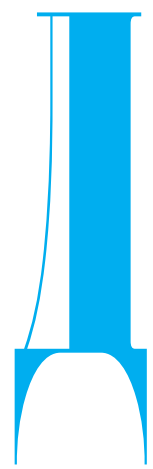

ГОРОВА A.I. БУЧАВИЙ Ю.В.

Державний ВНЗ "Національний гірничий університет", м. Дніпропетровськ

УДК 57.42: 528.88

Ключові слова: санітарно-захисна зона, озеленення території, вегетаційні індекси, промислові

підприємства, дистанційне зондування.

ніпропетровськ $€$ одним 3 потужних індустріальних центрів України, на території якого розміщується понад 30 містоутворюючих промислових підприємств енергетичної, металургійної, машинобудівельної, хімічної та інших галузей. Оскільки ці підприємства $€$ суттєвими джерелами хімічного та фізичного забруднення довкілля, навколо них утворюють санітарнозахисні зони.

Санітарно-захисна зона (С33) - це територія між межею промислового об'єкта або підприємства та житловою забудовою, зоною рекреації. Ширина С33 встановлюється залежно від класу небезпеки підприємства, що, у свою чергу, зумовлюється обсягами та характеристиками промислових викидів відповідно до наказу МОЗ [1]. Основні призначення СЗЗ - створення естетичного бар'єру та зменшення рівнів забруднювачів від викидів промислових підприємств до гранично допустимих концентрацій (ГДК) за межами СЗЗ.

ОЦЕНКА СТЕПЕНИ ОЗЕЛЕНЕНИЯ САНИТАРНО-ЗАЩИТНЫХ ЗОН ПРОМЫШЛЕННЫХ ПРЕДПРИЯТИЙ ДНЕПРОПЕТРОВСКА Горовая А.И., Бучавый Ю.В.

Цель работы: исследовать степень озеленения территорий санитарно-защитных зон промышленных предприятий Днепропетровска.

Материалы и методы. Для оценки степени озеленения территорий и качества зеленых насаждений использовался нормализованный относительный индекс растительности (NDVI). Для его расчета использовались мультиспектральные аэрофотоснимки, полученные из архивов съемки спутника Landsat 8. Обработка аэрофотоснимков, вычисление среднесезонных значений NDVI, а также их классификация с последующим зонально-статистическим анализом на территориях санитарно-защитных зон выполнялись в программе ESRI ARCMAP 9.

Результаты. Установлено, что зеленые насаждения на территориях санитарно-защитных зон размещены неравномерно. Значительная часть площадей СЗЗ промышленных предприятий характеризуется разряженной растительностью и открытым грунтом. В результате зонально-статистического анализа были выявлены предприятия, не соответствующие требованиям по количеству озеленяемой площади санитарно-защитных зон.

Ключевые слова: санитарно-защитная зона, озеленение территории, вегетационные индексы, промышленные предприятия, дистанционное зондирование.

๑) Горова А.І., Бучавий Ю.В. СТАТТЯ, 2016.

Саме зелені насадження відіграють значну роль у зменшенні та нейтралізації негативного впливу промислових підприємств. Дерева й чагарники забезпечують оздоровлення атмосферного басейну шляхом мінімізації концентрації у повітрі пилу і токсикантів, зменшення сили звукових хвиль, регулювання пилових та газових потоків, формування комфортного мікроклімату тощо [2]. При цьому, за нормативами [1] залежно від класу небезпеки підприємства, озеленення дерево-чагарниковими рослинами має бути не менш 40-60\%. Ефективність зниження негативного впливу від джерел забруднення на території СЗ3 зумовлюється площею території озеленення та якістю стану зелених насаджень.

За результатами роботи [3] було визначено, що на територіях С33 переважають такі рослини: ялина колюча, сосна звичайна, робінія звичайна, клен гостролистий, клен ясенелистий, горіх грецький, тополя чорна, тополя пірамідальна, тополя Боллє, в'яз гладкий, каштан кінський, айлант найвищий, вишня звичайна, абрикос звичайний, бузина чорна та бузок звичайний. При цьому середній вік насадження становить 25 років, середня висота у насадженні - близько $7 \mathrm{M}$.

На стан зелених насаджень санітарнозахисної зони впливають природні та антропогенні фактори, серед яких забруднення атмосферного повітря вважається одним із найвпливовіших [4]. Таким чином, виникає необхідність в оцінці ступеня озеленення територій санітарно-захисних зон та стану їхніх зелених насаджень. Отримати якісну оцінку стану рослин дозволяють методи біоіндикації. Однак для екс- 
їхніх вегетаційних індексів.

Матеріали та методи дослідження. Для експресоцінки якості зелених насаджень доцільно застосовувати нормалізований відносний індекс рослинності, тобто NDVI (Normalized Difference Vegetation Index) [5]. Це простий показник кількості фотосинтетичноактивної біомаси. Висока фотосинтетична активність призводить до меншого відображення у червоній області спектра і більшого - в інфрачервоній. Цей індекс розраховується за формулою 1:

$$
\mathrm{NDVI}=\frac{(\mathrm{NIR}-\mathrm{VIS})}{(\mathrm{NIR}+\mathrm{VIS})}
$$
часом стають більш доступними та популярними.

Мета: дослідити ступінь озеленення територіїй санітарнозахисних зон промислових підприємств Дніпропетровська. Для цього були вирішені такі задачі:

$\square$ проведено радіометричну та атмосферну корекцію мультиспектральних аерофотознімків Дніпропетровська за літній сезон 2015 року;

口 обраховано середньосезонні вегетаційні індекси зелених насаджень;

$\square$ проведено класифікацію та зонально-статистичний аналіз територій санітарнозахисних зон за показником де NIR - відображення у ближній інфрачервоній області спектра; VIS - відображення у червоній області спектра.

Необхідні для розрахунку індексів мультиспектральні аерофотознімки були отримані із архівів зйомки супутника Landsat 8 [6]. Для коректного розрахунку значень NDVI необхідно виконати радіометричне та атмосферне корегування аерофотознімків, отриманих у різний час за різних атмосферних умов. Згідно 3 документацією до супутника Landsat 8 [7] переведення зна- чень яскравості каналів із безрозмірної величини DN (Digital Number) до значень атмосферного планетарного відображення радіації TOA reflectance (Top of Atmosphere Reflectance) здійснюється за формулою 2:

$\rho \lambda=(\mathbf{M} \rho \times \mathbf{D N}+\mathbf{A} \rho) / \sin (\mathrm{SE}),(2)$ де $\rho \lambda-$ значення атмосферного планетарного відображення радіації каналу з урахуванням корекції за кутом падіння і відбиття сонячних променів, тобто Альбедо; Мр - специфічний мультиплікативний розрахунковий коефіцієнт посилення значення відображення каналу (REFLECTANCE MULT_BAND); А - специфічний мультиплікативний розрахунковий коефіцієнт для зміщення значення відображення каналу (REFLECTANCE_ADD_ BAND); DN - значення безрозмірної величини яскравості аерофотознімка; SE - висота Сонця над обрієм (SUN_ELEVATION).

Значення параметрів M та A визначається для кожного каналу окремо за допомогою файла метаданих *_MTL.txt, який входить до наборів аерофотознімків. Після радіометричної та атмосферної корекції каналів було виконано їх об'єднання у композитні зображення 3 метою підвищення

\section{Картографування території Сз3 промислових підприємств міста за класами NDVI}

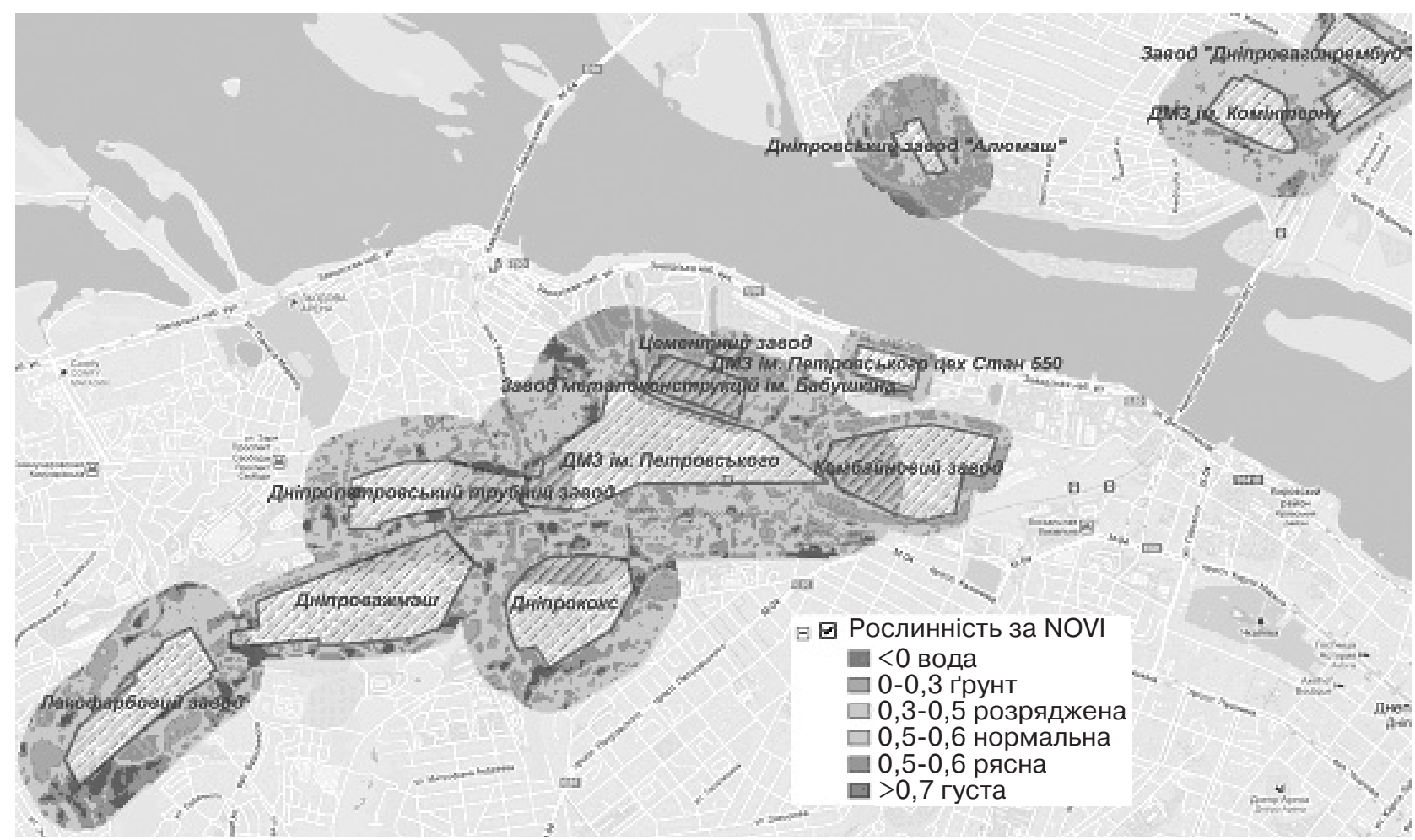


ASSESSMENT OF THE GREENERY PLANTING LEVEL IN SANITARY PROTECTION ZONES OF THE DNIPROPETROVSK INDUSTRIAL ENTERPRISES Horova A.I., Buchavy Yu.V.

Objective. We studied a level of the greenery planting in the sanitary protection zones (SPZ) of the Dnepropetrovsk industrial enterprises. Materials and methods. We applied the Normalized Difference Vegetation Index (NDVI) for the assessment of the level of territories' greening planting and the quality of green space. For its calculation we used the multispectral aerial photographs obtained from the archives of satellite imagery Landsat 8. Processing of aerial photos, calculation of average-seasonal values of the NDVI, as well as their classification with a further zonestatistical analysis at the territories of the SPZ were performed in the program ESRI ARCMAP 9.

Results. The green areas at the territories of the $S P Z$ were determined to be placed irregularly. A significant part of the SPZ territories of the industrial enterprises is characterized by rare vegetation and open soil. The enterprises that didn't meet the requirements for the amount of vegetated areas of the SPZ were revealed as a result of zone-statistical analysis.

Keywords: sanitary protection zone, greenery planting of the territory, vegetation indices, industrial enterprises, remote sensing. роздільної здатності аерофотознімків до 15 м на основі пан хроматичного зображення. Слід зазначити, що при панхроматичному зливі каналів були визначені їхні вагові коефіцієнти: синій - 0,05; зелений та червоний - 0,475, інфрачервоний - 0. Такі коефіцієнти зумовлюються специфікацією інструментів супутника Landsat 8, а саме: шириною каналів, що цілком або частково потрапляють до діапазону панхроматичного зображення.

Обробка аерофотознімків за звітний період та розрахунок середньосезонних значеннь NDVI виконувались у програмі ESRI ARCMAP 9.3. Після цього проведено класифікацію територій санітарно-захисних зон підприємств. Далі на основі інструментів зональної статистики (Spatial Analyst $\backslash$ Zonal Tabulate area) було розраховано площі С33 за класифікацією за показником NDVI.

Результати та їх обговорення. Результати картографування території С3З промислових підприємств міста за ступенем її озеленення згідно з класифікацією значень NDVI наведено на рисунку 1.

Як бачимо з рисунка, санітарно-захисні зони підприємств накладаються одна на одну, що зумовлено близьким розташуванням промислових ділянок та підсилює негативний вплив забруднювачів на рослини. Зелені насадження на територіях С33 розміщені нерівномірно: переважає розряджена рослинність, але у деяких місцях рослини розташовані групами. Розподіл сумарної площі санітарно-захисних зон за класами NDVI наведено на рисунку 2, з якого видно, що переважна кількість площі СЗЗ промисло-

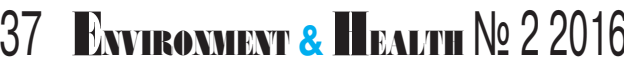

вих підприємств характеризується 3 та 2 класом, тобто розрядженою рослинністю та відкритим ґрунтом. Результати оцінки ступеня озеленення санітарно-захисних зон промислових підприємств Дніпропетровська за показником NDVI зведено до таблиці.

\section{Висновки}

У результаті проведеного аналізу було встановлено, що за показником озеленення території С33 не відповідають вимогам такі підприємства: НТЗ "Інтерпайп", ДЗ Алюмаш, Комбайновий завод та Завод металоконструкцій ім. Бабушкіна. Такий підхід доцільно також застосовувати для контролю ступеня озеленення окремих районів міста, територій промислових підприємств, а також примагістральних смуг.

\section{ЛІТЕРАТУРА}

1. Державні санітарні правила планування та забудови населених пунктів : ДСП 17396 / МОЗ України. К., 1996.
2. Кучерявий В.П. Озеленення населених місць : підручник / В.П. Кучерявий. - Львів : Світ, 2005. - 456 с.

3. Іванченко О.Є. Видовий склад та стан зелених насаджень санітарно-захисної зони підприємства ПАТ

«Дніпротяжмаш» [Електронний ресурс] / О.Є. Іванченко, А.Д. Чередниченко. - Режим доступу: http://www.rusnauka. com/38_NIEK_2014/Biologia/2 182390.doc.htm

4. Удосконалення методів оцінки якості атмосферного повітря з використанням рослин-індикаторів та геоінформаційних технологій / А.І. Горова, Ю.В. Бучавий, А.В. Павличенко, І.Г. Миронова // Екологічна безпека та природокористування : зб. наук. пр. - К., 2014. Вип. 14. С. 5358.

5 . Monitoring vegetation systems in the Great Plains with ERTS / J.W. Rouse, R.H. Haas, J.A. Schell, D.W. Deering // 3-rd ERTS Symposium. NASA SP351. - Washington, 1973. Vol. I. P. 309-317.

Рисунок 2

\section{Розподіл сумарної площі санітарно-захисних зон за класами NDVI}

ХАРАКТЕРИСТИКА РОСЛИННОСТІ ЗА ПОКЗНИКОМ NDVI

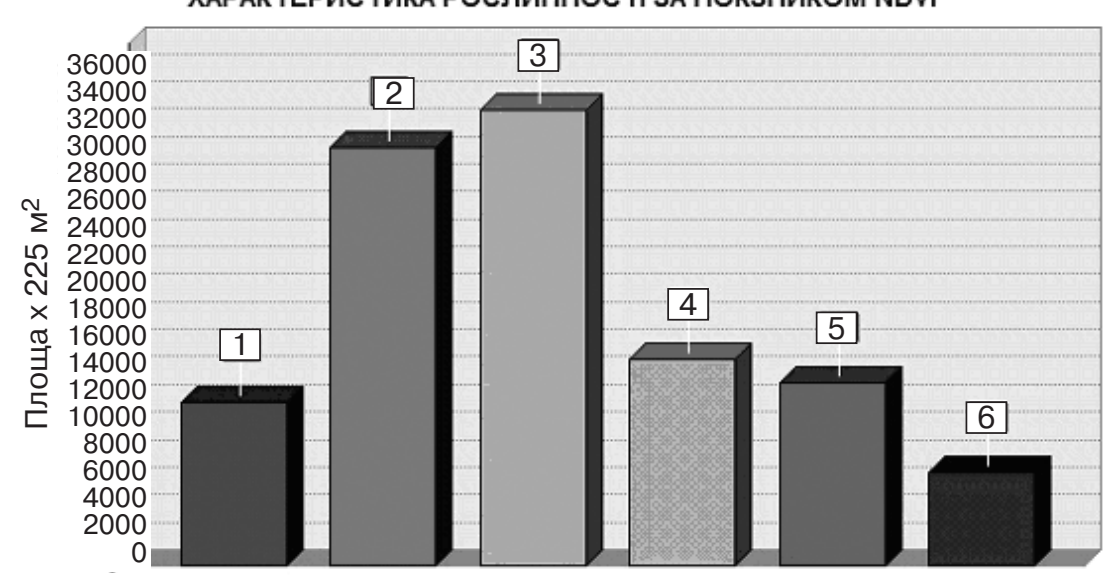

Класи за значеннями NOVI 
6. U.S. Department of the Interior U.S. Geological Survey [Електронний ресурс]. Режим доступу: http://earthexplorer.usgs.gov.

7. LANDSAT 8 (L8) Data Users Handbook, LSDS1574, Version 1.0 / Department of the Interior U.S. Geological Survey [Електронний ресурс]. - South Dakota, 2015. Режим доступу : http://www.greenpolicy360.net/mw/images/ Landsat8DataUsersHandbook. pdf

\section{REFERENCES}

1. MOZ Ukrainy Derzhavni sanitarni pravyla planuvannia ta zabudovy naselenykh punktiv: DSP 17396 [National Sanitary Rules for Planning and Building of the Settlements : NSR 17396] . Kyiv, 1996

(in Ukrainian).

2. Kucheryavyi V.P. Ozelenennia naselenykh mists : pidruchnyk [Landscaping of the
Settlements : Manual]. Lviv : Svit ; 2005 : 456 p. (in Ukrainian).

3. Ivanchenko O.Ye., Cherednychenko A.D. Vydovyi sklad ta stan zelenykh nasadzhen sanitarnozakhysnoi zony pidpryiemstva PAT «Dniprotiazhmash» [Species Structure and State of Green Spaces of the Sanitary Protective Zone at the Public Joint Stock Company

Dniprotiazhmash Enterprise]. Available at : http://www.rusnauka.com/38_NIEK_2014/Biol ogia/2 182390.doc. $\overline{\text { htm (in }}$ Ukrainian).

4. Horova A.I., Buchavyi Yu.V., Pavlychenko A.V., Myronova I.H. Udoskonalennia metodiv otsinky yakosti atmosfernoho povitria iz vykorystanniam roslynindykatoriv ta heoinformatsiinykh tekhnolohii [Improvement of the Methods for the Ambient Air Quality Assessment with the Help of
PlantsIndicators and Geoinformation Technologies]. In : Ekolohichna bezpeka ta pryrodokorystuvannya [Ecological Safety and Nature

Management]. Kyiv ; 2014 ; 14 : 5358 (in Ukrainian).

5. Rouse J.W., Haas R.H., Schell J.A., Deering D.W.

Monitoring Vegetation Systems in the Great Plains with ERTS. In : 3-rd ERTS Symposium.

Washington : NASA ; 1973 : 309-317.

6. U.S. Department of the Interior U.S. Geological Survey. Available at : http://earthexplorer.usgs.gov.

7. LANDSAT 8 (L8) Data Users Handbook, LSDS1574, Version 1.0 / Department of the Interior U.S. Geological Survey. South Dakota ; 2015. Available at: http://www.greenpolicy360.net/ $\mathrm{mw}$ /images/Landsat8DataUser sHandbook.pdf

Надійшла до редакції 25.12.2015

Таблиця

Ступінь озеленення санітарно-захисних зон промислових підприємств Дніпропетровська за показником NDVI та характеристика щільності рослинності

\begin{tabular}{|c|c|c|c|c|c|c|c|c|}
\hline Підприємтво & ○ $\underset{0}{\stackrel{0}{0}}$ & 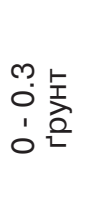 & 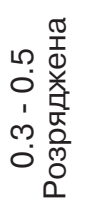 & 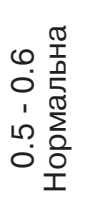 & 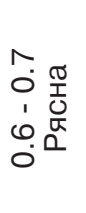 & 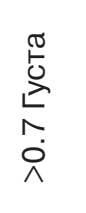 & 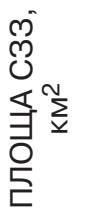 & 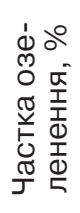 \\
\hline Придніпровська ДРЕС & 41.6 & 8.6 & 17.2 & 12.7 & 15.7 & 4.2 & 5.9 & 49.8 \\
\hline Дніпропрес & 1.1 & 31.0 & 27.0 & 16.2 & 16.5 & 8.2 & 1.2 & 67.9 \\
\hline НТ3 "Інтерпайп" & 1.5 & 51.1 & 33.4 & 9.3 & 3.6 & 1.1 & 4.7 & 47.4 \\
\hline Вторчормет & 0.0 & 47.6 & 44.1 & 6.8 & 1.5 & 0.0 & 0.3 & 52.4 \\
\hline Вилковий завод & 0.0 & 20.9 & 47.1 & 16.4 & 11.5 & 4.0 & 0.4 & 79.1 \\
\hline Дніпротяжбудмаш & 0.0 & 43.0 & 47.8 & 8.1 & 1.1 & 0.0 & 0.1 & 57.0 \\
\hline Дніпрошина & 0.0 & 11.3 & 19.6 & 15.4 & 25.4 & 28.4 & 1.7 & 88.7 \\
\hline Південний машинобудівельний завод & 0.0 & 16.8 & 25.9 & 17.7 & 19.5 & 20.1 & 0.9 & 83.2 \\
\hline ДЗ Алюмаш & 3.1 & 64.7 & 22.2 & 6.1 & 2.6 & 1.3 & 0.6 & 32.3 \\
\hline ДМЗ ім. Комінтерна & 0.0 & 10.5 & 64.5 & 17.0 & 6.9 & 1.2 & 0.7 & 89.5 \\
\hline Завод прокатних валків & 0.0 & 26.5 & 58.0 & 14.5 & 1.0 & 0.0 & 0.1 & 73.5 \\
\hline Завод "Дніпровагонрембуд" & 0.0 & 13.8 & 50.4 & 24.3 & 10.5 & 1.0 & 0.2 & 86.2 \\
\hline Вагоноремонтний завод & 0.0 & 27.2 & 53.4 & 14.0 & 4.8 & 0.6 & 0.3 & 72.8 \\
\hline Комбайновий завод & 0.0 & 57.2 & 33.0 & 8.4 & 1.5 & 0.0 & 0.2 & 42.8 \\
\hline ДМЗ ім. Петровського, цех Стан 550 & 0.0 & 30.3 & 52.7 & 8.1 & 6.1 & 2.8 & 0.1 & 69.7 \\
\hline ДМЗ ім. Петровського & 0.1 & 41.0 & 34.5 & 13.2 & 8.2 & 3.1 & 2.3 & 58.9 \\
\hline Дніпрококс & 0.0 & 19.8 & 32.0 & 23.5 & 18.6 & 6.1 & 0.9 & 80.2 \\
\hline Лакофарбовий завод & 0.0 & 21.4 & 32.2 & 15.8 & 19.1 & 11.5 & 1.1 & 78.6 \\
\hline Дніпропетровський трубний завод & 0.0 & 21.3 & 41.9 & 19.3 & 12.9 & 4.6 & 1.0 & 78.7 \\
\hline Дніпроважмаш & 0.0 & 13.0 & 37.6 & 21.8 & 17.1 & 10.5 & 0.4 & 87.0 \\
\hline Цементний завод & 0.0 & 50.0 & 25.9 & 18.5 & 5.6 & 0.0 & 0.0 & 50.0 \\
\hline Завод металоконструкцій ім. Бабушкіна & 0.0 & 59.7 & 32.5 & 4.2 & 2.6 & 1.0 & 0.2 & 40.3 \\
\hline
\end{tabular}

